\title{
Democracia e direitos sociais: histórico e implicações para as políticas educacionais brasileiras
}

\author{
Doracy Dias Aguiar de Carvalho' \\ https://orcid.org/0000-0001-6992-1615
}

\author{
Roberto Francisco de Carvalho ${ }^{2}$ \\ http://orcid.org/0000-0001-7278-181X
}

${ }^{1}$ Universidade Federal do Tocantins, Campus Universitário de Palmas, Coordenação de Estágio e Assistência Estudantil (Coest), Palmas, TO, Brasil.

${ }^{2}$ Universidade Federal do Tocantins, Campus Universitário de Palmas, Curso de Licenciatura em Filosofia e Mestrado Profissional em Educação, Palmas, TO, Brasil.

\begin{abstract}
Democracia e Direitos Sociais: histórico e implicações para as políticas educacionais brasileiras Resumo: Este texto discute a temática da democracia no âmbito da sociedade capitalista e é resultado de uma pesquisa teóricodocumental que busca demarcar conceitualmente os limites da democracia substantiva, de natureza socialista, e da democracia liberal representativa. Evidencia algumas implicações da democracia liberal para os direitos sociais e as políticas públicas brasileiras, que vêm sendo desmontadas pelas contrarreformas neoliberais, a exemplo da educação. Expõe, ainda, a necessidade da luta em defesa de uma educação de caráter nacional-popular capaz de contribuir para a construção de uma democracia substantiva e de uma nova sociabilidade, que pressuponha relações de igualdade e a articulação entre política e economia na perspectiva da emancipação humana.
\end{abstract}

Palavras-chave: Democracia. Direitos Sociais. Políticas Públicas. Educação.

\section{Democracy and Social Rights: History and Implications for Brazilian Educational Policies}

Abstract: This article discusses democracy within the scope of the capitalist society, using theoretical and documentary research. The study sought to build concepts around the limits of substantive, socialist, and representative liberal democracy. It shows some implications of liberal democracy for Brazilian social rights and public policies that have been dismantled by neoliberal counter-reforms, such as the policies on education. The study also exposes the need to protect national-popular education, capable of contributing to the construction of substantive democracy and new sociability, which implies in relations of equality and coordination between politics and economy from the perspective of human emancipation.

Keywords: Democracy. Social rights. Public policy. Education.

Recebido em 11.01.2019. Aprovado em 16.04.2019. Revisado em 24.07.2019.

(C) O(s) Autor(es). 2019 Acesso Aberto Esta obra está licenciada sob os termos da Licença Creative Commons Atribuição-NãoComercial 4.0 Internacional (https://creativecommons.org/licenses/by-nc/4.0/deed.pt_BR), que permite copiar, distribuir e reproduzir em qualquer meio, bem como adaptar, transformar e criar a partir deste material, desde que para fins não comerciais e que você forneça o devido crédito aos autores e a fonte, insira um link para a Licença Creative Commons e indique se mudanças foram feitas. 


\section{Introdução}

Neste texto situa-se, historicamente, o debate da democracia no seio da sociedade capitalista onde o conceito em questão encontra-se em constante disputa e é permeado por tensões advindas das correlações de forças sociais antagônicas que defendem distintos projetos de sociedade e de democracia. Entende-se que este é um debate fundamental, especialmente no contexto atual marcado por sucessivos retrocessos relacionados aos direitos civis, políticos, e, sobretudo sociais.

Busca-se entender qual a diferença entre a democracia substantiva, de viés socialista e a democracia liberal representativa e quais as implicações dessas perspectivas democráticas para as políticas públicas e os direitos sociais, a exemplo da educação. A partir de autores como Wood $(2001 ; 2006)$, Harvey $(2005 ; 2008)$ e Behring (2016), o estudo objetiva compreender as implicações das mencionadas concepções de democracia para as políticas sociais brasileiras, especialmente as políticas educacionais, que vêm sendo alvo de sucessivas reformas direcionadas ao favorecimento do capital, na perspectiva do projeto democrático liberal fundado na democracia formal e na supremacia do mercado.

Além da introdução e conclusão, o texto discute a democracia substantiva acima aventada e suas implicações para as políticas sociais brasileiras, bem como aborda o direito à educação, seus avanços e retrocessos no âmbito da luta de classes.

\section{A democracia substantiva ou para além do capitalismo}

Ao tratarem da temática da democracia, os estudiosos, em sua maioria, remetem-se à Grécia antiga como berço do seu nascimento, a partir da experiência ateniense de governo em que o povo era o soberano. No entanto, historicamente, o conceito de democracia foi sendo ressignificado e, entre as várias concepções existentes na atualidade, esta pode ser compreendida apenas como o direito ao voto ou pode significar "a reversão do governo de classe, em que o demos, o homem comum, desafia a dominação dos ricos". (WOOD, 2006, p. 7). Tais concepções opõem, de um lado, os defensores da democracia liberal/ representativa - compatível com um capitalismo reformado e humanizado - e, de outro, os que refutam a possibilidade de conciliação entre democracia substantiva e capitalismo, ainda que defendam reformas democráticas e o aprofundamento dos direitos.

Como forma política, a democracia liberal representativa tornou-se hegemônica na atualidade, mas passa ao largo do que consiste a democracia grega - governo do povo -, que requer a articulação entre o político e o econômico ${ }^{1}$ como condição para a emancipação humana, impossível sem a superação da sociedade burguesa e o estabelecimento de relações sociais igualitárias, sem classes e hierarquias (MARX, 2010; LESSA, 2007).

A democracia substantiva, fundamentada na experiência ateniense, baseia-se na liberdade do demos $=$ povo em relação ao senhorio e no rompimento da oposição ancestral entre governantes e produtores, livrando os cidadãos do domínio do senhorio, típico das sociedades pré-capitalistas. Tal domínio ocorria por mecanismos político-jurídicos como coação direta para pagamento de dívidas, escravidão, servidão, tributos, impostos, corveia e outros meios de apropriação da produção das comunidades por parte dos governantes. Atenas buscou um modelo de organização política que uniu proprietários e camponeses, numa unidade cívica e militar, o que representou um avanço em relação a outras civilizações do mundo antigo. Tratava-se de uma democracia direta, substantiva, pautada nos princípios da isegoria (garantia do direito do cidadão à palavra e à emissão de opiniões públicas nas ruas, tribunais e assembleias) e da isonomia, (igualdade de todos perante a lei). Os considerados cidadãos participavam, ativa e igualmente, do espaço público, e, como trabalhadores e cidadãos, decidiam os rumos políticos da polis, cuja democracia baseava-se no trabalho livre, oposta à democracia liberal/formal, fundada no trabalho não livre ou assalariado. A democracia substantiva consiste, portanto, em recuperar a noção de trabalho livre no processo produtivo e rearticular economia e política, o que inclui os direitos civis, políticos e sociais e não exclui a luta de classes (WOOD, 2006).

O modelo de democracia ateniense foi questionado pela oposição oligárquica, que defendia outra forma de governo das Cidades-Estados e refutava a participação política dos não proprietários, que não dispunham de tempo livre. Na medida em que a sociedade capitalista foi se forjando e engendrando novas relações políticas, econômicas e sociais, o capitalismo passou a desprezar a ideia da democracia substantiva e a instituir sua ordem, por meio da "[...] desapropriação, extinção dos direitos consuetudinários, imposição dos imperativos do mercado e destruição ambiental". (WOOD, 2001, p. 126) Gradativamente, os elementos da sociedade capitalista foram se formando no seio da velha sociedade (feudal), que foi se dissolvendo juntamente com suas condições de existência. Nesse contexto, "[...] as ideias cristãs cederam lugar às ideias iluministas, a sociedade feudal travava sua batalha decisiva contra a burguesia então revolucionária. As ideias de liberdade religiosa e 
de consciência não fizeram mais do que proclamar o império da livre concorrência no domínio do conhecimento". (MARX; ENGELS, 1998, p. 57).

Com o advento da modernidade e o surgimento da sociedade burguesa, a democracia distanciou-se do seu sentido original e passou a sustentar-se nas ideias dos contratualistas - principalmente de Locke - que fundamentaram a edificação do Estado liberal e sua relação com a sociedade civil. Ao discordar de Hobbes quanto ao Estado absoluto, Locke defendia que este deveria garantir os direitos fundamentais dos indivíduos, assim, o liberalismo constituiu-se tendo por princípios fundamentais a vida, a liberdade e a propriedade privada. O Estado é concebido pelos liberais como instância separada da sociedade, e, como tal, não deve afetar-se por fatores sociais e econômicos, nem se preocupar em prestar serviços à sociedade e em mantê-la em equilíbrio. "Fortalece-se, desse modo, o conceito de igualdade formal e jurídica, que, por assim ser, não assumia compromissos com a desigualdade real, substantiva". (PEREIRA, 2007, p. 30, grifo do autor).

Contrariando a ideia do Estado como instância separada da sociedade, Harvey (2005) afirma que a constituição do Estado liberal resulta das relações concretas e contraditórias historicamente estabelecidas pela sociedade civil e permeadas por interesses individuais, particularistas e antagônicos, em que o Estado assume caráter de classe no seio das relações capitalistas de produção. Nessa mesma direção, Pereira (2009, p. 144) afirma que o Estado é uma criação da sociedade, um fenômeno histórico que "[...] não existe de forma absoluta e inalterável, ou sujeito a uma ordem cujos valores e fins estejam previamente definidos [...]". Tratase de uma organização do poder fundada na política como atividade humana, "[...] uma construção mundana (e não divina) prevista primeiramente por Hobbes - com vistas à preservação da vida em sociedade". (PEREIRA, 2009, p. 144). Deve ser considerado não como um sistema acabado, mas como algo em mutação e em movimento constante, pois, "como processo histórico, o Estado contém em si uma dinâmica que articula passado, presente e futuro. O passado nunca é completamente superado, porque se infiltra no presente e se projeta no futuro". (PEREIRA, 2007, p. 144-145).

A constituição da sociedade capitalista e do Estado liberal colocou em xeque a relação do homem com a natureza, como condição elementar para a reprodução da vida humana, e estabeleceu um sistema social baseado em classes, em que uma (a dos trabalhadores) subordina-se à outra (a dos proprietários dos meios de produção). Com o estabelecimento do contrato de compra e venda da força de trabalho, os capitalistas passaram a explorar a mão de obra dos trabalhadores e extrair dela a mais-valia, que possibilita o lucro e a acumulação de capital e que transforma toda a capacidade e produção humana em mercadorias. "[...] até a capacidade humana de trabalho é uma mercadoria à venda no mercado [...] como todos os agentes econômicos dependem do mercado, os requisitos da competição e da maximização do lucro são as regras fundamentais da vida". (WOOD, 2001, p. 12).

Assim, na democracia liberal o poder político do povo é limitado, o que inviabiliza um capitalismo governado pelo poder popular, em que a vontade do povo sobreponha-se aos imperativos do lucro e da acumulação e estes não definam as condições mais básicas de vida, lógica que impossibilita ao capitalismo conciliar-se com a democracia substantiva na perspectiva ateniense.

Compreendendo-se que a democracia substantiva é incompatível com o capitalismo e que o Estado é resultado do processo histórico, permeado por relações e interesses de classes, discute-se, a seguir, a concepção de democracia liberal representativa, buscando evidenciar suas implicações e limites à participação sociopolítica no âmbito das sociedades ditas democráticas.

\section{A democracia liberal representativa: o povo distante do poder}

A ideia de democracia baseada na concepção grega predominou até o final do século XVIII, confrontando-se abertamente aos interesses da classe dominante que buscava conter a ideia de uma democracia de massa e passa a adotar estratégias ideológicas para limitá-la, reformulando seu conceito. Na segunda metade do século XIX ampliavam-se as mobilizações pela democracia de massa, bem como as vantagens ideológicas para as classes dominantes sobre a redefinição da democracia e seu direcionamento a uma política eleitoral de massa, limitada ao voto. (WOOD, 2006).

As classes dominantes passaram a pressionar e a exigir, não somente a alienação do poder democrático, "mas, a separação entre a 'democracia' e o 'demos' - ou, no mínimo, o afastamento decidido do poder popular como principal critério de valor democrático". (WOOD, 2006, p. 196). Numa situação tensa e contraditória, de um lado, explicitava-se a repugnância das classes dominantes pela democracia de massa, e, do outro, seu reconhecimento de que era impossível evitá-la.

Diante disso, a ideia de democracia foi reformulada, tendo como um de seus principais colaboradores John Stuart Mill “De um lado, ele demonstrou evidente repugnância pelas tendências 'niveladoras' e pela 
'mediocridade coletiva' da democracia de massa [...] de outro, a defesa dos direitos da mulher e do sufrágio universal [...]" (WOOD, 2006, p. 196). Mudou-se, então, o foco da democracia e esta passou do exercício ativo do poder popular para o gozo passivo das salvaguardas e dos direitos constitucionais e processuais; do poder coletivo das classes subordinadas para a privacidade e isolamento do cidadão individual.

Conforme Wood (2006, p. 196), o discurso do liberalismo entrou na modernidade não apenas visando limitar o poder do rei, mas como substituto da democracia, como um "projeto contra revolucionário - ou no mínimo um meio de conter as revoluções já em andamento, não permitindo que ultrapassassem limites aceitáveis". Sendo assim, a reformulação teórica e ideológica da democracia por parte dos federalistas americanos nada tem a ver com a perspectiva grega/ateniense, pois sua inspiração fundamenta-se no feudalismo europeu, que culminou no capitalismo liberal, em que as classes proprietárias foram libertas do senhorio feudal e das reivindicações da monarquia. Não foi o demos - governo que equilibra o poder entre ricos e pobres - o critério da democracia moderna. Ao contrário, trata-se de um governo limitado, fundado na separação dos poderes entre classes, que privilegia o fortalecimento dos proprietários e governantes e o enfraquecimento dos produtores/trabalhadores e governados, condenando o povo à passividade.

Dessa maneira, a efetivação da democracia substantiva na sociedade capitalista é impossível devido ao isolamento das relações de propriedade entre capital e trabalho, de um lado, e, de outro, a democratização dos direitos políticos e civis. Com essa cisão, a igualdade se dá somente no plano dos direitos formais e não na garantia real - econômica - relativa às condições de vida de seus cidadãos, sobretudo, quanto à produção e ao gozo desses direitos (WOOD, 2006). Portanto, a democracia grega como governo pelo demos - governo de muitos, inclusive dos pobres - contrasta com a democracia liberal representativa - governo pelos ricos legitimado pelos pobres por meio do sufrágio universal - que se desloca para a esfera puramente política, distinta e separada da sociedade civil, isto é, da economia. Essa separação articula-se intimamente com o capitalismo e possibilita "uma forma de democracia em que a igualdade formal de direitos políticos tem efeito mínimo sobre as desigualdades ou sobre as relações de dominação e de exploração em outras esferas". (WOOD, 2006, p. 193).

Atrelado ao processo de redefinição teórico-ideológico da democracia liberal redefiniu-se, também, o conceito de sociedade civil, que, segundo Wood (2006) passou a ser considerada democrática, liberta do poder do Estado, lugar do pluralismo, do culto à diferença e à diversidade e onde realiza-se a emancipação por meio da formalização dos direitos diversificados. Essa concepção de sociedade civil tem sido compartilhada por parte da esquerda, que, ao refutar a luta em defesa do socialismo, abraça a defesa da democracia inclusiva, que privilegia as políticas diferenciadas em detrimento das políticas universais e entende que a emancipação ocorrerá no âmbito do extraeconômico, pela emancipação de gênero, raça, dentre outras. Wood (2006) não descarta a importância das políticas de identidades, mas afirma que estas são limitadas, teórica e politicamente, pois distanciam-se da perspectiva de classe e da esfera econômica, em que a emancipação deve ser buscada respeitando a pluralidade da experiência humana, sem desconsiderar a causalidade histórica. Por isso, a autora defende que "a comunidade democrática ideal une seres humanos diferentes, todos livres e iguais, sem suprimir suas diferenças nem negar suas necessidades especiais". (WOOD, 2006, p. 221).

Do exposto anteriormente, depreende-se que a democracia liberal representativa, de concepção norteamericana, distancia-se da perspectiva substantiva ao negar uma cultura democrática preexistente - nesse caso a cultura democrática pré-revolucionária norte-americana - e provoca o distanciamento do povo em relação ao poder e à participação da esfera pública. Trata-se de uma perspectiva de cidadania expansiva, inclusiva e passiva, que contrasta com a democracia ateniense, mais política e participativa. Em outras palavras, a democracia liberal exclui o conteúdo social, pois o povo perde o controle político sobre o governo e sobre as políticas sociais e passa, de forma passiva, a legitimar decisões governamentais que, em muitos casos, contrariam os seus próprios interesses.

Dessa forma, pode-se dizer que, pelo menos, na forma federalista, a democracia representativa norteamericana representa a negação do autogoverno democrático, e, mais, significa a renúncia do poder político pela população e sua transferência a outros pela alienação, ou seja, trata-se da perda do controle sobre os governantes por parte do povo.

\section{Implicações da democracia liberal representativa para as políticas sociais brasileiras}

O liberalismo clássico, sustentado, especialmente, no princípio do trabalho como mercadoria e na sua regulação pelo livre mercado, marcou profundamente o período que vai de meados do século XIX e até a terceira década do século XX, orientado pelas ideias de David Ricardo, e, principalmente, de Adam Smith. As teses desses economistas, balizadoras da ação do Estado liberal, baseiam-se na defesa de que cada indivíduo, atuando junto a uma coletividade de indivíduos, ao agir em seu próprio interesse econômico, 
maximizaria o bem estar coletivo, de modo que o funcionamento - livre e ilimitado - do mercado, conduzido por sua mão invisível, regularia as condições econômicas e socais e produziria o bem comum. O sucesso regulador do mercado, segundo Smith, só é possível pela ausência da intervenção estatal juntamente com a "[...] existência de um corpo de leis e a ação do Estado que garantisse maior liberdade ao mercado livre". (BEHRING; BOSCHETTI, 2008, p. 56-57).

Os princípios do liberalismo clássico sustentam-se: a) no individualismo e na ideia de que o bem-estar individual amplia o bem-estar coletivo; b) na liberdade e competitividade; c) na naturalização da miséria compreendida como algo natural e insolúvel e não como resultado do acesso desigual à riqueza socialmente produzida; d) na lei da necessidade, baseada nas teses malthusianas de que a não satisfação de todas as necessidades humanas é eficaz no controle do crescimento populacional e no consequente controle da miséria; e) na manutenção de um Estado mínimo, que assume papel neutro de legislador e árbitro e desenvolve apenas ações complementares ao mercado restritas à regulação das relações sociais para garantir a liberdade individual, a propriedade privada e o livre mercado; e f) na ideia de que as políticas sociais estimulam o ócio e o desperdício, reproduzem a miséria e desestimulam o interesse pelo trabalho - o que gera acomodação e representa risco para a sociedade e o mercado - e de que tais políticas devem ser apenas um paliativo, pois a pobreza deve ser minorada pela caridade privada. (BEHRING; BOSCHETTI, 2008).

\section{[...] a democracia substantiva, que articula direitos políticos}

e a socialização econômica, parece ter se transformado numa utopia a ser recolocada, urgentemente, como bandeira de luta da classe

trabalhadora, utopia essa, que se considera realizável, mas que deve ser alcançada pela luta política travada no campo econômico e ideológico.

Na segunda metade do século XIX o avanço da industrialização, o crescimento das massas trabalhadoras e os conflitos sociais provenientes da relação capital e trabalho criaram problemas complexos para o Estado capitalista devido à eclosão da questão social, que evidenciou a incapacidade da autorregulação do mercado e impôs ao Estado a necessidade de mudança nas suas funções para responder à problemática social de forma efetiva e ampliada (PEREIRA, 2007). Para tanto, o Estado lançou mão da doutrina keynesiana, que, ao contrário da teoria liberal clássica, defendia a intervenção estatal como forma de reativar a produção e retomar as taxas de lucros, o que demandava: "a regulação do mercado; a formação e controle dos preços; a emissão de moedas; a imposição de condições contratuais; a distribuição de renda; o investimento público; o combate à pobreza etc.". (PEREIRA, 2007, p. 32-33). Tais medidas visavam apenas à socialização do consumo, concebido como um contraponto à socialização da produção. Diante disso, a proteção social passou a ser considerada direito do cidadão e dever do Estado, representando um aperfeiçoamento político-institucional importante no âmbito da regulação estatal, o que não ocorreu sem conflitos de classes, visto que os trabalhadores abraçaram a luta por direitos sociais e pelo compromisso do Estado com a melhoria das suas condições de vida e trabalho. (PEREIRA, 2007).

A implementação dessas políticas e as reivindicações da classe trabalhadora geraram novas contradições entre o Estado de direito e o Estado social, isto é, entre os direitos individuais ligados às liberdades burguesas (pessoal, política e econômica) e os direitos sociais ligados à igualdade e à justiça social (participação no poder político e na distribuição da riqueza socialmente produzida), prevalecendo os direitos individuais em detrimento dos direitos sociais. (PEREIRA, 2007). Assim, a década de 1970 - que registra o surgimento de uma nova crise estrutural do capital - marca o esgotamento da perspectiva de regulação keynesiano-fordista das relações econômicas, políticas e sociais e do compromisso firmado entre as classes sociais voltados ao crescimento econômico, com impacto na estrutura das desigualdades sociais por meio de políticas sociais ${ }^{2}$ amplas e universais (BEHRING; BOSCHETTI, 2008).

Nesse contexto, entra em cena a doutrina neoliberal, que, segundo Harvey (2008) objetivava restabelecer as condições de acumulação do capital e restaurar o poder das elites econômicas. O neoliberalismo tornouse discurso hegemônico e passou a afetar amplamente os modos de pensamento, incorporando-se às maneiras cotidianas de muitas pessoas interpretarem, viverem e compreenderem o mundo, pois, "Nenhum modo de pensamento se torna dominante sem propor um aparato conceitual que mobilize nossas sensações e nossos instintos, nossos valores e nossos desejos, assim como as possibilidades inerentes ao mundo social que habitamos". (HARVEY, 2008, p. 13). 
O neoliberalismo se consolidou, portanto, a partir dos "[...] ideais políticos da dignidade humana e liberdade individual, tomando-os como 'os valores centrais da civilização'. Assim agindo, fizeram uma sábia escolha, porque esses certamente são ideais bem convincentes e sedutores". (HARVEY, 2008, p. 15) Esse processo, capitaneado por Margareth Thatcher, objetivava extinguir as instituições e práticas políticas do Estado social democrata, que se consolidara a partir de 1945. Isso envolvia, segundo Harvey (2008), o enfrentamento do poder sindical; $\mathrm{o}$ ataque às formas de solidariedade social que prejudicassem a flexibilidade competitiva; $\mathrm{o}$ desmantelamento ou revisão dos compromissos do Estado de bem-estar social; a privatização das empresas públicas; a redução de impostos; a promoção da iniciativa dos empreendedores e a criação de um clima de negócio favorável à indução de um forte fluxo de investimento externo. Nessa mesma direção, Navarro (2015) aponta a redução dos salários e a destruição do emprego; o ataque aos movimentos sociais e partidos esquerda; o crescimento da concentração de renda e das desigualdades sociais; e a ampliação das dívidas e dos déficits públicos, cuja redução exige corte de gastos públicos relativos ao bem-estar da população.

Portanto, desde a década de 1970, o Estado tem sido reconfigurado, sobretudo, quanto ao equilíbrio entre coerção e consentimento, entre os poderes executivo e judiciário, de um lado, e os poderes da democracia representativa, de outro. Com isso, a substituição dos serviços públicos por serviços privados tem sido maciça e, na medida em que isso acontece, o Estado tende a confiar mais nos mecanismos econômicos privados para substituir a mobilização ativa e passiva de seus cidadãos, de modo que, a participação no mercado substitui a participação na política e o consumidor toma o lugar do cidadão (HOBSBAWM, 2007). Esse processo, que traduz a nova ideia de cidadania, distancia-se da cidadania substantiva - calcada na distribuição da produção e na possibilidade de o cidadão ser dirigente e controlar o poder dos que dirigem - e traz, dentre outras consequências, o esvaziamento dos regimes democráticos e a ampliação contínua do desinteresse das pessoas pelos assuntos de natureza pública.

No caso brasileiro, no tocante às políticas sociais, Behring e Boschetti (2008, p. 147) assinalam que "os anos de 1990 até os dias de hoje têm sido de contrarreforma do Estado e de obstaculização e/ou redirecionamento das conquistas de 1988, num contexto em que foram derruídas até mesmo aquelas condições políticas por meio da expansão do desemprego e da violência." Consequentemente, a tendência geral tem sido a restrição de direitos - sob o argumento do desemprego e da crise fiscal do Estado -, e a transformação das políticas sociais em ações compensatórias, direcionadas aos efeitos mais perversos da crise. Assim:

[...] a configuração dos padrões universalistas e redistributivos de proteção social foi fortemente tencionada: pelas estratégias de extração dos superlucros, em que se incluem as tendências de contração dos encargos sociais e previdenciários; pela supercapitalização, com a privatização explícita ou induzida de setores de utilidade pública em que se incluem saúde, educação e previdência; e pelo desprezo burguês para com o pacto social dos anos de crescimento, configurando um ambiente ideológico individualista, consumista e hedonista ao extremo. Tudo isso num contexto em que as forças de resistência se encontram fragmentadas, particularmente o movimento dos trabalhadores, em função do desemprego, da precarização e flexibilização das relações de trabalho e dos direitos. (BEHRING; BOSCHETTI, 2008, p. 155-156).

Desta forma, a construção de um sistema de proteção social no Brasil não se concretizou, ao contrário, o que vem ocorrendo é o aprofundamento das contrarreformas neoliberais que resultam na perda sucessiva de direitos. Esse processo, intensificado nas áreas social, econômica e política, tem como uma de suas partes constitutivas o golpe midiático, jurídico e parlamentar executado em 2016, que teve como "[...] objetivo precípuo trocar os atuais mandatários por outros mais reacionários, os quais, não constrangidos por qualquer passado combativo e sindical, podem agora realizar o ajuste fiscal, tudo isso no grau, no ritmo e na intensidade exigidos pelo capitalismo brasileiro em crise". (DEMIER, 2017, p. 91, grifo do autor). Esse tipo de golpe, segundo Boron (2009), trata-se de uma estratégia imperialista que substitui os golpes militares realizados na América Latina e que vem sendo realizada por governos ditos democráticos, eleitos pelo voto popular, mas claramente dirigidos pelo mercado. No Brasil, o referido golpe possibilitou ao governo uma ação intensa para implementar medidas repressoras de direitos, como aponta Behring (2016, p. 16) ao apresentar levantamento feito por Hoeveler:

[...] há cerca de 66 projetos que atacam os direitos humanos, especialmente os direitos sociais e trabalhistas; sete que acometem o serviço público, 27 que acometem os trabalhadores, sete que tratam do Banco Central e empresas públicas, 6 que atingem as mulheres e a população LGBT, oito que atingem indígenas e trabalhadores do campo, e dez que ampliam mecanismos de repressão sobre as lutas sociais.

Pode-se mencionar, ainda, a proposta de reforma da previdência, em discussão, e a aprovação da contrarreforma trabalhista e da Proposta de Emenda Constitucional (PEC n ${ }^{\circ}$ 95/2016) (BRASIL, 2016), que 
congela investimentos na educação e na saúde pública por 20 anos, como meio de forçar a precarização desses serviços e justificar sua privatização em prol do capital.

Do ponto de vista democrático vem havendo um esforço ideológico para despolitizar a sociedade civil como esfera de explicitação das lutas, concebendo-a como espaço da não política, por meio da adoção de medidas que geram desinteresse social pela política (BORON, 2009). Assim, a democracia liberal representativa submete-se à lógica do mercado - responsável por ordenar todas as esferas da vida social - e torna-se imprescindível às estratégias de reprodução da ordem social vigente.

Diante disso, a democracia substantiva, que articula direitos políticos e a socialização econômica, parece ter se transformado numa utopia a ser recolocada, urgentemente, como bandeira de luta da classe trabalhadora, utopia essa, que se considera realizável, mas que deve ser alcançada pela luta política travada no campo econômico e ideológico.

Para os propósitos deste texto uma das arenas ideológicas consideradas importante é, para além da própria sociedade burguesa econômico-corporativa, a busca da realização de uma educação ético-política e nacional-popular, conforme discutido a seguir.

\section{O direito à educação no Brasil: luta de classes, avanços e retrocessos}

A condução da gestão democrática, no Brasil, é fruto da democracia liberal, baseada nos princípios do liberalismo cujos mecanismos de funcionamento vêm por meio da representação do povo, que elege seus representantes. Essa perspectiva de democracia como regime político, com abordagens elitista, pluralista - em que a vontade de todos se institui a partir da vontade de cada indivíduo, em contraposição à vontade geral e ao bem comum - tem dominado a primeira década do século XXI. (CARVALHO, 2016).

Nesse sentido, pensar a democracia, evidenciando a vontade geral, caminha no sentido do fortalecimento da esfera pública e do interesse comum em relação à esfera privada mercantil e ao interesse particular. No caso brasileiro, a esfera privada e o interesse particular sempre estiveram presentes ao se tratar do processo educativo, mas isto não significa que os ideais liberais de democracia tenham inexistido em momentos importantes da história do País.

Não é difícil identificar, que, no Brasil, o Estado, por meio da sociedade política, tem exercido um papel educador que atrela, fortemente, a educação aos interesses econômicos internacionais, voltados à gestão do capital e à produção de mercadorias. Nessa lógica, historicamente, tem sido adotada a individualização, divisão e fragmentação do processo de reprodução da vida social em busca da eficiência na produção das diversas mercadorias, dentre elas a educação. (CARVALHO, 2011).

Decorrente da forma de gestão do capital, a gestão da educação tem sofrido um processo de reforma, pretensamente, com o objetivo de melhorar o sistema educacional, temática que tem ganhado destaque nos debates educacionais, nos quais defende-se uma perspectiva de administração democrática, participativa, orientada por preceitos legais - artigos 13, 14 e 56 da Lei no 9.394/1996 (BRASIL, [2019b]) - asseguradores da existência do trabalho coletivo, da escolha de dirigentes, dos colegiados e conselhos que contribuam para a superação de uma gestão centralizadora e autoritária. Ao que tudo indica tais mecanismos não têm sido suficientes para promover uma participação efetiva, pois, apesar do discurso e da base legal mencionada, não é raro ouvir relatos evidenciadores de certa conformação dos trabalhadores da educação quanto à concepção de gestão de viés empresarial e produtivista adotada nas instituições educacionais.

Entende-se, nessa direção, que a democratização não ocorrerá como dádiva, mas como resultado de lutas organizadas e mobilizadas em favor de um projeto de sociedade e de educação que tenha como princípios e pressupostos a democracia participativa e emancipatória e não a liberal democracia representativa, o gerencialismo estratégico-empresarial e mercadológico. Tomando como referência o pensamento gramsciano, trata-se de uma concepção de democracia progressiva que, no entendimento de Carvalho (2011, p. 75):

[...] de um lado, possibilita fazer a crítica ao modelo de democracia liberal representativa de cunho minimalista, orientadora dos processos de produção e reprodução da vida social brasileira, e, portanto, orientadora do processo de participação das organizações empresariais e instituições sociais. De outro lado, possibilita, sem negar as conquistas da democracia liberal, vislumbrar novas possibilidades democráticas que extrapolam os limites da representatividade parlamentar e institucional. Estamos falando de uma democracia efetivamente participativa que assegure as regras liberais do jogo democrático, combinadas com participação direta nos diversos níveis governamentais distribuídos no âmbito da sociedade civil e sociedade política, com destaque para a aparelhagem de governo. 
Compreende-se que a essa perspectiva de democracia é viabilizada a partir do vínculo organicamente articulado entre as esferas estrutural e superestrutural, como ação de retorno ativa, possibilitador de participação política efetiva nos processos de tomada de decisões propícias à construção da hegemonia numa perspectiva emancipadora e democrático-popular.

Nesse sentido, o direito formal à educação, como valor público, expresso na Constituição Federal Brasileira de 1988 (CF/1988), garante a educação como “[...] direito de todos e dever do Estado e da família [...]" (BRASIL, [2019a]). Esse direito, traduzido em políticas públicas disputadas pela classe trabalhadora cuja operacionalização ocorre por meio das ações que concretizam a gestão educacional no território nacional - se coloca, também, como espaço de luta política em busca da conquista de uma educação éticopolítica e nacional-popular.

O valor público formal aventado, evidentemente, não se materializa de forma espontânea, mas por meio da luta permanente da classe trabalhadora, que viabiliza as condições materiais (disponibilidade financeira: capital/ custeio e recursos humanos) e condições imateriais relacionadas, em geral, às circunstâncias políticas que envolvem constante negociação e conflito abrangendo as forças sociopolítica e econômica em âmbito nacional e local.

Desde, pelo menos, o século XVII a luta pelo direito a educação já se fazia presente e encontrava forte resistência entre pensadores como Voltaire (1694-1778) (apud CUNHA, 1980, p. 37) para o qual "A canaille não é 'digna' de esclarecimento", pois "[...] qualquer esforço despendido na instrução da criadagem e dos sapateiros era, simplesmente, um desperdício de tempo". Mas é, também, remota a manifestação escrita daqueles que defendiam a educação como um direito a ser garantido pelo Estado, a exemplo de Denis Diderot (1713-1784) (apud CUNHA, 1980, p. 38), para quem “[...] é desejável que todos soubessem ler, escrever e contar, desde os ministros de Estado até o último dos camponeses".

A luta pelo direito a educação que incluísse todos, pelo menos formalmente, é histórica e própria da sociedade capitalista, mas, no caso brasileiro, esta só ganhou status constitucional mais amplo na CF de 1988 (BRASIL, [2019a]) (artigos $6^{\circ}, 205,206$ e 208), conforme mencionado anteriormente. Inicialmente, a garantia do direito subjetivo à educação circunscreveu-se ao ensino fundamental - dos 7 aos 14 anos -, somente a partir de 2009 a Educação Básica obrigatória e gratuita passou a abranger a faixa etária dos 4 aos 17 anos de idade, por meio da Emenda Constitucional n. 59/2009, (BRASIL, 2009). A Educação Infantil, em creche e pré-escola, também passou a ser obrigatória às crianças de até 5 anos de idade, a partir da Emenda Constitucional n ${ }^{\circ} 53 /$ 2006 (BRASIL, [2006]).

Na Lei no 9.394/96 (BRASIL, [2019b]) de Diretrizes e Bases da Educação Nacional (LDB), alterada pelas Leis $\mathrm{n}^{\mathrm{o}}$ 12.061/2009 (BRASIL, [2009]) e ${ }^{\circ}$ 11.700/2008 (BRASIL, [2008]), o artigo $4^{\circ}$, Incisos II e X, respectivamente, estabelecem que o dever do Estado com educação pública será efetivado por meio da "[...] universalização do ensino médio gratuito" e da oferta de "[...] vaga na escola pública de educação infantil ou de ensino fundamental mais próxima de sua residência a toda criança a partir do dia em que completar 4 (quatro) anos de idade". (BRASIL, [2019b]).

O ponto de partida, segundo a CF de 1988, é a garantia das condições materiais necessárias à efetivação do direito à educação. Quanto à garantia de qualidade, esta implica tanto a existência de pessoal qualificado, quanto de equipamentos e instalações adequadas. Para tanto, o artigo 212 da referida Constituição estabelece percentuais mínimos de investimentos em educação pública pelos entes federados, sendo: União 18\%, estados e municípios não menos que $25 \%$. Ainda, conforme a CF de 1988, a garantia constitucional do direito à educação não se limita à oferta de vagas (artigo 206), mas estende-se às garantias de condições relativas à permanência dos alunos na escola, à continuidade dos estudos e à qualidade (artigo 211). (BRASIL, [2019a]).

Especificamente sobre a permanência na escola e a continuidade dos estudos, o artigo 208 da CF em questão aponta ações de suporte ao aluno que visam assegurar sua frequência à escola e as condições mínimas ao bom desenvolvimento de seus estudos, operacionalizadas por programas governamentais vinculados ao Fundo Nacional de Desenvolvimento da Educação (FNDE). Para tanto, de acordo com o Plano Nacional de Educação (PNE) 2014-2024, é necessário garantir: as condições para acesso e permanência dos estudantes; estrutura e funcionamento das escolas; valorização dos trabalhadores e trabalhadoras em educação; e realização da gestão democrática (BRASIL, [2014]).

Conforme exposto, a educação continua sendo um importante espaço de luta política no campo do direito à democratização do conhecimento científico, cultural do campo da arte e da Filosofia, com abrangência nacional-popular.

As conquistas democrático-populares relativas à educação, ocorridas no Brasil, em grande medida, são frutos do engajamento político da sociedade civil nas lutas e disputas por direitos sociais, como os educacionais, formalizados na CF de 1988. Tais direitos consistem em: ensino fundamental obrigatório e gratuito; progressiva universalização do ensino médio gratuito; atendimento educacional especializado aos portadores de deficiência; atendimento em creche e pré-escola às crianças; acesso aos níveis mais elevados do ensino, da pesquisa 
e da criação artística; atendimento ao educando, no ensino fundamental, através de programas suplementares de material didático-escolar, transporte, alimentação e assistência à saúde; acesso ao ensino obrigatório e gratuito como direito público subjetivo; acesso das minorias e dos economicamente desfavorecidos à universidade, entre outros. (CARVALHO, 2016).

Entretanto, as conquistas acima aventadas encontram-se constantemente ameaçadas pela elite brasileira e vêm se aprofundando, sobretudo, a partir de 2016, com o governo de Michel Temer, e agora continuadas pelo governo de Bolsonaro, que defende o aprofundamento da privatização da educação em todos os níveis, conforme as diretrizes neoliberais adotadas no Brasil desde a década de 1990.

Como parte da privatização da educação, o PNE 2014-2024 favorece claramente a oferta da educação por instituições privadas, que já comandam 75\% das vagas na educação superior (LEHER, 2014). Isso evidencia a subsunção do direito à educação aos interesses mercadológicos do capital, cujo domínio abrange não somente a oferta de vagas, mas, também, o currículo escolar, estruturado em consonância com padrão de reprodução capitalista.

A supressão e ameaça aos direitos sociais, como a educação, recoloca, também, a urgência da intensificação das lutas da classe trabalhadora em diversas frentes de ações, dentre estas, o campo ideológico educacional que pode ser importante instrumento no fortalecimento da hegemonia dominante. Contraditoriamente, este campo pode ser também, portador de um projeto ético-político de sociedade capaz de contribuir para a produção de um bloco sociocultural e político de cunho democrático-popular efetivamente democrático e inclusivo.

\section{Considerações finais}

Nos termos de Wood (2006) é possível afirmar que a democracia substantiva - como mecanismo de busca da igualdade econômica, social, política e de emancipação humana - é incompatível com o capitalismo em razão da sua estrutura de classe, que socializa a produção e privatiza sua apropriação, garantindo a prevalência das desigualdades sociais e os interesses de uma minoria privilegiada, que se sustenta pela exploração dos trabalhadores. Dada à sua natureza, o capitalismo, coaduna apenas com uma democracia que não ultrapasse os limites da formalidade e da representação, base da democracia liberal. Nesse modelo - que responde aos interesses da burguesia - a política está separada da economia e as decisões políticas cabem aos representantes do povo, em geral, fortemente vinculados aos interesses dos grandes proprietários e do mercado, e não dos seus representados.

Sendo assim, a democracia liberal representativa tem sido útil à reprodução capitalista, pois impede, literalmente, a participação do povo nas decisões políticas de seus países. A delegação do poder do povo aos seus representantes favorece práticas políticas que reforçam os interesses do mercado e a adoção de medidas antidemocráticas, que contrariam os interesses da classe trabalhadora, a exemplo do que vem ocorrendo no Brasil, por meio do desmonte dos direitos sociais - como a educação - e das instituições democráticas. Esse processo, aprofundado a partir do golpe de 2016, vem ocorrendo por meio da privatização do patrimônio e dos serviços públicos lucrativos; da redução de direitos sociais; e da destinação do fundo público para pagamento de juros e encargos da dívida pública, em detrimento dos investimentos em políticas sociais publicas direcionadas ao bem-estar da população.

O desmonte das conquistas sociais de 1988, como o direito à educação, impõe a necessidade de ampliar e potencializar a luta dos trabalhadores organizados em prol da manutenção e expansão dos direitos sociais, a serem disputados via conquista das políticas públicas. No campo educacional, os direitos devem ser materializados por intermédio da gestão pública educacional participativa, voltada para a defesa de um projeto de educação nacional-popular que promova uma formação crítica capaz de contribuir, efetivamente, para a construção de uma sociedade democrática e emancipada.

Nesse sentido, a perspectiva de democracia a ser buscada é viabilizada, em termos gramscianos, a partir do vínculo organicamente articulado da esfera estrutural com a esfera superestrutural, como ação de retorno ativa, consequentemente, possibilitadora da participação política efetiva nos processos de tomadas de decisões propícias à construção da hegemonia em uma perspectiva emancipadora e democrático-popular.

Portanto, é imprescindível aprofundar não apenas a luta por direitos no âmbito da cidadania política, mas é necessário que a classe trabalhadora, busque de forma articulada, a emancipação humana que pressupõe, a extinção da exploração de classes, a unificação entre política e economia e a superação do capitalismo. Contudo, a luta pela superação da sociedade capitalista, conforme Boron (2009), passa, necessariamente, pelo conhecimento crítico da sua estrutura e dinâmica e pela organização e intensificação das lutas sociais numa perspectiva ampla e coletiva (política e econômica), tendo-se claro o caminho a ser trilhado como perspectiva de uma nova sociabilidade. 


\section{Referências}

BEHRING, E. R. A condição da política social e a agenda da esquerda no Brasil. Revista SER Social, Brasília, v. 18, n. 38, p. 13-29, jan./ jun. 2016.

BEHRING, E. R.; BOSCHETTI, I. Política social: fundamentos e história. 5. ed. São Paulo: Cortez, 2008.

BORON, A. A. Hegemonía e imperialismo en el sistema internacional. In: BORGIANNI, E.; MONTAÑO, C. (org.). Coyuntura actual, latinoamericana y mundial: tendencias y movimientos. São Paulo: Cortez, 2009, p. 136-163.

BOSCHETTI, I. Assistência social e trabalho no capitalismo. São Paulo: Cortez, 2018.

BRASIL. [Constituição (1988)]. Constituição Da República Federativa do Brasil de 1988. Brasília, DF: Presidência da República, [2019a]. Disponível em: http://www.planalto.gov.br/ccivil_03/constituicao/ConstituicaoCompilado.htm. Acesso em: 24 jul. 2019.

BRASIL. [Constituição (1988)]. Emenda Constitucional no 53, de 19 de dezembro de 2006. Dá nova redação aos arts. 7º 23, 30, 206, 208, 211 e 212 da Constituição Federal e ao art. 60 do Ato das Disposições Constitucionais Transitórias. Brasília, DF: Presidência da República, [2006]. Disponível em: http://www.planalto.gov.br/ccivil_03/constituicao/Emendas/Emc/emc53.htm. Acesso em: 24 jul. 2019.

BRASIL. [Constituição (1988)]. Emenda Constitucional no 59, de 11 de novembro de 2009.

Acrescenta $\S 3^{\circ}$ ao art. 76 do Ato das Disposições Constitucionais Transitórias para reduzir, anualmente, a partir do exercício de 2009 , o percentual da Desvinculação das Receitas da União incidente sobre os recursos destinados à manutenção e desenvolvimento do ensino de que trata o art. 212 da Constituição Federal, dá nova redação aos incisos I e VII do art. 208, de forma a prever a obrigatoriedade do ensino de quatro a dezessete anos e ampliar a abrangência dos programas suplementares para todas as etapas da educação básica, e dá nova redação ao $\S 4^{\circ}$ do art. 211 e ao $\S 3^{\circ}$ do art. 212 e ao caput do art. 214, com a inserção neste dispositivo de inciso VI. Brasília, DF: Presidência da República, [2009]. Disponível em: http://www.planalto.gov.br/ccivil_03/constituicao/Emendas/Emc/emc59.htm. Acesso em: 24 jul. 2019.

BRASIL. [Constituição (1988)]. Emenda Constitucional n 95, de 15 de dezembro de 2016. Altera o Ato das Disposições Constitucionais Transitórias, para instituir o Novo Regime Fiscal, e dá outras providências. Brasília, DF: Presidência da República, [2016]. Disponível em: http://www.planalto.gov.br/ccivil_03/constituicao/Emendas/Emc/emc95.htm. Acesso em: 24 jul. 2019.

BRASIL. Lei $n^{\circ}$ 9.394, de 20 de dezembro de 1996. Estabelece as Diretrizes e Bases da Educação Nacional. Brasília, DF: Presidência da República, [2019b]. Disponível em: http://www.planalto.gov.br/ccivil_03/LEIS/L9394.htm. Acesso em: 24 jul. 2019.

BRASIL. Lei $n^{\circ} 11.700$, de 13 de junho de 2008. Acrescenta inciso X ao caput do art. 4o da Lei n ${ }^{\circ}$ 9.394, de 20 de dezembro de 1996, para assegurar vaga na escola pública de educação infantil ou de ensino fundamental mais próxima de sua residência a toda criança a partir dos 4 (quatro) anos de idade. Brasília, DF: Presidência da República, [2008]. Disponível em: http://www.planalto.gov.br/ccivil_03/ _Ato2007-2010/2008/Lei/L11700.htm. Acesso em: 24 jul. 2019.

BRASIL. Lei $n^{\circ}$ 12.061, de 27 de outubro de 2009. Altera o inciso II do art. $4^{\circ}$ e o inciso VI do art. 10 da Lei no 9.394, de 20 de dezembro de 1996, para assegurar o acesso de todos os interessados ao ensino médio público. Brasília, DF: Presidência da República, [2009]. Disponível em: http://www.planalto.gov.br/ccivil_03/_Ato2007-2010/2009/Lei/L12061.htm. Acesso em: 24 jul. 2019.

BRASIL. Lei $n^{\circ}$. 13.005, de 25 de junho de 2014. Aprova o Plano Nacional de Educação - PNE e dá outras providências. Brasília, DF: Presidência da República, [2014]. Disponível em: http://www.planalto.gov.br/ccivil_03/_ato2011-2014/2014/lei/113005.htm. Acesso em: 24 jul. 2019.

CARVALHO, R. F. de. A constituição do Estado brasileiro na tensão entre o domínio e a direção de classe: a educação como arena éticopolítica. In: VILAS BÔAS, J. P. S.; NETO, L. F.; PERIUS, O. (org.). Filosofia em Debate: questões de ética, educação e política. Florianópolis: Néfiponline, 2016, p. 207-240.

CARVALHO, R. F. de. O processo de gestão e participação na universidade: limites, possibilidades e desafios na UFT. 2011. Tese (Doutorado em Educação) - Faculdade de Educação, Universidade Federal de Goiás, Goiânia, 2011.

CUNHA, L. A. Educação e desenvolvimento social no Brasil. 5. ed. Rio de Janeiro: Francisco Alves, 1980.

DEMIER, F. Depois do Golpe: a dialética da democracia blindada no Brasil. Rio de Janeiro: Mauad X, 2017.

HARVEY, D. O neoliberalismo: história e implicações. São Paulo: Loyola, 2008.

HARVEY, D. A produção capitalista do espaço. São Paulo: Annablume, 2005.

HOBSBAWM, E. Globalização, democracia e terrorismo. São Paulo: Companhia das Letras, 2007.

LEHER, R. Organização, estratégia política e o Plano Nacional de Educação. [São Paulo]: [s. n.], 2014. Disponível em: https:// marxismo21.org/wp-content/uploads/2014/08/R-Leher-Estrat\%C3\%A9gia-Pol\%C3\%ADtica-e-Plano-NacionalEduca\%C3\%A7\%C3\%A3o.pdf. Acesso em: 6 dez. 2018.

LESSA, S. A Emancipação Política e a defesa de direitos. Serviço Social e Sociedade, São Paulo: Cortez, n. 90, p. 35-57, jun. 2007.

MARX, K. Sobre a questão judaica. São Paulo: Boitempo, 2010.

MARX, K.; ENGELS, F. Manifesto Comunista. São Paulo: Boitempo, 1998.

NAVARRO, V. Ataque a la democracia y ao bienestar: crítica ao pensamiento económico dominante. Barcelona: Anagrama, 2015.

PEREIRA, P. A. P. Estado, regulação social e controle democrático. In: BRAVO, M. I. S.; PEREIRA, P. A. P. Política social e democracia. 3. ed. São Paulo: Cortez; Rio de Janeiro: UERJ, 2007. p. 25-42.

PEREIRA, P. A. P. Política Social: temas \& questões. 2. ed. São Paulo: Cortez, 2009. 
WOOD, E. M. Democracia contra capitalismo: a renovação do materialismo histórico. São Paulo: Boitempo, 2006.

WOOD, E. M. A origem do capitalismo. Rio de Janeiro: Zahar, 2001.

\section{Notas}

1 Na democracia ateniense, ainda que coexistissem igualdade política e desigualdade socioeconômica, e escravos, mulheres, crianças e estrangeiros fossem excluídos da participação política, o povo participava diretamente das decisões relativas à polis. Tratava-se de uma democracia substancial, em que as liberdades política e econômica eram inseparáveis e as desigualdades socioeconômicas eram modificadas por meio da ação política, o que não ocorre na democracia liberal. (WOOD, 2006).

2 As políticas sociais são incapazes de "[...] emancipar a humanidade do modo de produção capitalista, mas instituíram sistemas de direitos e deveres que, combinados com a instituição de tributação mais progressiva e a ampliação do fundo público, alteraram o padrão de desigualdade entre as classes sociais, sobretudo a partir da segunda metade do século XX”. (BOSCHETTI, 2018, p. 25), reduzindo as distâncias entre rendimentos e acesso aos bens e serviços.

\section{Doracy Dias Aguiar de Carvalho}

doracy@uft.edu.br

Mestrado em Educação pela Universidade Federal de Goiás (UFG)

Assistente Social da Universidade Federal do Tocantins (UFT) - Campus Universitário de Palmas

\section{UFT}

Endereço: Quadra 109 Norte, Avenida NS-15, ALCNO-14, Plano Diretor Norte

Palmas -Tocantins - Brasil

CEP: 77001-090

\section{Roberto Francisco de Carvalho}

carvalho1917@gmail.com

Doutorado em Educação pela Universidade Federal de Goiás (UFG)

Professor Associado da Universidade Federal do Tocantins (UFT) - Campus Universitário de Palmas.

\section{UFT}

Endereço: Quadra 109 Norte, Avenida NS-15, ALCNO-14, Plano Diretor Norte

Palmas/Tocantins/Brasil

CEP: 77001-090

\section{Agradecimentos}

Ao Programa de Pós-Graduação em Política Social da Universidade de Brasília (UnB) pela sua contribuição com a formação cidadã em uma perspectiva democrática e emancipadora.

Agência financiadora

Não se aplica

Contribuições das autoras

Não se aplica

\author{
Aprovação por Comitê de Ética e consentimento para parti- \\ cipação \\ Não se aplica \\ Consentimento para publicação \\ Não se aplica \\ Conflito de interesses \\ Não há conflito de interesses.
}

